\title{
Job Satisfaction Effecting Factors of Employees in Bangladesh Banking Sector
}

\author{
Md Sohel Rana \\ National Bank Limited, Dhaka, Bangladesh \\ Email address: \\ msrana_7@yahoo.com \\ To cite this article: \\ Md Sohel Rana. Job Satisfaction Effecting Factors of Employees in Bangladesh Banking Sector. International Journal of Economics, \\ Finance and Management Sciences. Vol. 3, No. 4, 2015, pp. 352-357. doi: 10.11648/j.ijefm.20150304.14
}

\begin{abstract}
Satisfaction of employees with their job is considered one of the key factors for the success of an organization. The job satisfaction has got tremendous attention in organizational research. The focus of this study is to determine the impact of various human resource management practices like job autonomy, team work environment and leadership behavior on job satisfaction. It also investigates the major determinants of job satisfaction in Bangladeshi banking sector. This study further evaluates the level of difference in job satisfaction among male and female employees. The sample of the study consisted of 450 employees working in different branches of bank in Bangladesh through the questionnaire, of which 295 were returned and processed. SPSS was used to analyze the data, using independent sample T test, Correlation and regression analysis. There is a positive and significant link between job satisfaction and human recourse management practices like team work environment, job autonomy and behavior of leadership. From the findings of the study, it is also inferred that male and female workers have significantly different level of job satisfaction.
\end{abstract}

Keywords: Bangladesh, Human Resource Management, Job Satisfaction, Bank Employees, Banking Sector

\section{Introduction}

The issue of job satisfaction is widely discussed in the literature on organizational behavior. There is a lot of work on the issue of job satisfaction which reveals that it reduces the rate of absenteeism and turnover. Various dimensions and determinants of the issue are discussed in the literature. A large number of practitioners, academicians and researchers are agreed on several important determinants of job satisfaction like team work environment, job autonomy, behavior of leadership, organizational commitment and nature of work. But they are not sure about the impact of each of these determinants in different conditions and environments. Investment in technology, accumulation of capital and other resources, or changes in strategies are some of the ways used to increase productivity. Better human resource management (HRM) practices also play a central role in enhancement of productivity of an organization (Bloom \& Van Reenen, 2007). HRM practices may also affect employee turnover and productivity may increase (Sels et al., 2006). Petrescu and Simmons (2008) find that HRM practices increase satisfaction with pay and their overall job satisfaction. However, these effects are almost insignificant for union members. Workers satisfaction with leadership behavior and with pay is more where performance based pay and seniority related reward systems are practiced.

Ivancevich et al. (1997) defined job satisfaction as feeling and perception of a worker regarding his/her work and how he or she feels himself well in an organization. According to Davis and Newstrom (1999) job satisfaction is an experience which has various aspects. The most significant aspects are those which are relevant to working conditions and the nature of work. Low job autonomy, low job security, low wages and lack of expectation for promotion negatively affect job satisfaction of employees (Guest, 2004 and Silla et al., 2005).

Garrido et al. (2005) conducted the research to discover the factors that determine the job satisfaction of sales managers. The effect of HRM practices is analyzed by using the model which was already employed by an empirical study on Spanish industrial firms. The study concludes that human resource management practices based on compensation type, compensation level and job design in terms of autonomy and resources are the essential determinants of sales managers' job satisfaction. Job satisfaction consists of overall or general job satisfaction, as well as a variety of satisfaction facets (Voon et. al., 2011)

Teams are performing, improving their own value added 
work and ability directed by their own plan without traditional direct enforcement. A team or group of people in work area (Dunkerley, 1975) direction is provided by top management and alignment with customers also. Dynamic changes in a company are only possible with complete understanding of management. An effective management has capability to understand failure in a team work.

The concept autonomy has its roots in political, bioethical and moral attitude. Having this background, it represents the capacity to make an unforced and informed decision by a rational individual. In the literature of political and moral philosophy, autonomy is considered as a foundation for determination of moral responsibility for an individual's actions. This term also refers to state of the self governing of the people (Smith, 1993). Leadership create the eagerness for improvement in productivity, growth and abilities of workers by building perception of organization based on the principles of love, sincerity and care to achieve the objective of loyalty of workers with organizations (Aydin\&Ceylan, 2009). Business or political leadership is considered as a formal aspect of leadership while leadership among the friends is its informal aspect. The term leadership normally refers that the person who is entitled to lead has some competencies or 'leadership skills' (Gill et al., 2010). The growing complex and volatile business environment, rapid technological change and increasing competition require that the organization should use their resources efficiently to get the competitive edge. Being an essential part of an organization, skilled workers are significant and reliable source of competitiveness. Loyal and committed workers are the key source of success of a business. Job satisfaction is an important determinant of worker performance at the workplace. For more than a decade banking sector in Bangladesh is experiencing a remarkable growth. The firms involve in the banking business are faced with growing competition due to entry of new firms. In order to survive in the competitive market, the firms have to focus on the provision of enhanced quality banking services at cheaper prices. In such competitive environment, the retention of well trained and skilled workforce is the major issue of the banking sector in the country. Different human resource practices are being adopted to retain their human resources. The focus of this study is to determine the impact of various human resource management practices like job autonomy, team work environment and leadership behavior on employee job satisfaction. It also investigates the major determinants of job satisfaction in Bangladeshi banking sector. This study further evaluates the level differences in job satisfaction between male and female employees.

\section{Research Theory}

Impact of different factors on job satisfaction has been analyzed in the literature. Some studies focus on demographic determinants of workers job satisfaction but, the others relate it with nature of work and working conditions at the workplace. Similarly, fair promotion system in the organization, job autonomy, leadership behaviour, social relations and the job itself are also among the important factors of job satisfaction (Dawson, 1987).

The effect of rank, age, gender and length of service on job satisfaction of employees was studied by Oshagbemi (2003) for the universities in United Kingdom. The study found individual's rank within the organization as a major predictor of job satisfaction and there was positive and strong correlation between the two. Similarly the length of service was significantly and negatively correlated to the job satisfaction. But the relationship between job satisfaction and age and gender was found to be insignificant for employees of the UK universities.

There is a lot of discussion in literature on the role of gender in job satisfaction but, there is a great controversy in the findings of different studies. Some studies found that women employees are more satisfied with their jobs than men employees but, the other studies on the gender issue prove the opposite (Weaver, 1974; Shaprio \& Stern, 1975; Forgionne and Peters, 1982; Clark, 1997; Ward \& Sloane, 1998). While discussing the gender aspect of job satisfaction, Cambell et al. (1976) argued that there is a difference between the expectations of men and women regarding their jobs. According to him this difference in expectation may be the cause of difference in the level of job satisfaction between women and men.

According to Lee and Ho (1989) participation of employees in decision making process adds positively in employee's job satisfaction. Job satisfaction and work motivation among the managers of Chinese restaurant in Hong Kong was studied by Lam et al. (2001). The result of the study showed that the job itself, work environment and rewards are the important determinants of job satisfaction in that industry.

They found that turnover intentions have a significant relation with job satisfaction. According to Tanke (1990) unpleasant behaviour of supervisor, dissatisfaction with compensation system and disagreement with human resource practices make employees willing to leave the organization. Using the longitudinal data, Nguyen et al. (2003) studied the determinants of job satisfaction by including personal traits, job autonomy, working hours, leadership behavior, actual pay and relative. There are three types of teams in organizations that are termed as quality circles, employee involvement teams, and self- directed work teams. According to Eason (1989) lack of training, insufficient support of top management and workers union and non-supportive behaviour of super- visors are major impediments in building empowered teams.

Despite prevalence of out dated system in an organization empowered work teams may work and flourish, but ultimately it will require the revision to improve the organization's system (Emery, 1992). Improper planning is among the biggest mistakes made at the time of team building and attractive reward system is the easiest thing to forget. For the prosperity and survival of self directed teams, intrinsic as well as extrinsic reward systems play a vital role 
(Hackman, 1990). Chow and Luk (1996) identified good working relationships with supervisors. It is very important to look into the factors behind the declining job satisfaction.

Satisfaction level of the employees working as a team is very important because it directly affects their performance on the job. Identification of these factors accurately becomes the key to retain and raise the satisfaction level of the employees (James, 1996). The controversy in the literature, regarding the relationship between level of job satisfaction and gender, leads the following hypothesis:

H0: There is no significant difference between men and women' job satisfaction level.

H1: There is a significant difference between men and women job satisfaction level.

$\mathrm{H} 2$ : Autonomy has significant impact on job satisfaction

Garrido et al. (2005) studied the factors that determine the job satisfaction of sales managers. The study concludes that human resource management practices based compensation type, compensation level and job design in terms of autonomy and resources are the essential determinants of sales managers' job satisfaction.

H3: Leadership behavior has significant impact on job satisfaction.

Markow and Klenke (2005) and Milliman et al. (2003) documented that leadership spiritually is a major determinant to enhance the employees' efficiency, job satisfaction, and loyalty coupled with a decrease in employees' turnover intentions. According to Hackmanand Oldham (1980) job satisfaction is a multifaceted phenomenon that consists of factor such as supervision at work, work itself, compensation and benefits, pro- motion policies of organization, appraisal and coworkers' attitude. People are much concern about pay and leadership behavior.

H4: Team work environment has significant impact on job satisfaction

Patel and Cardon (2010) suggest that having a group culture is a key factor in the extent to which leadership behavior is adopted, as well as how effective adopting HRM practices are for increasing labor productivity and job satisfaction. Gogoi (2005) find that the importance of work spiritually is consistently growing as the spiritual cause leads to strategic benefits to the business unit and due to the significant contribution of team work spiritually (Figure 1).

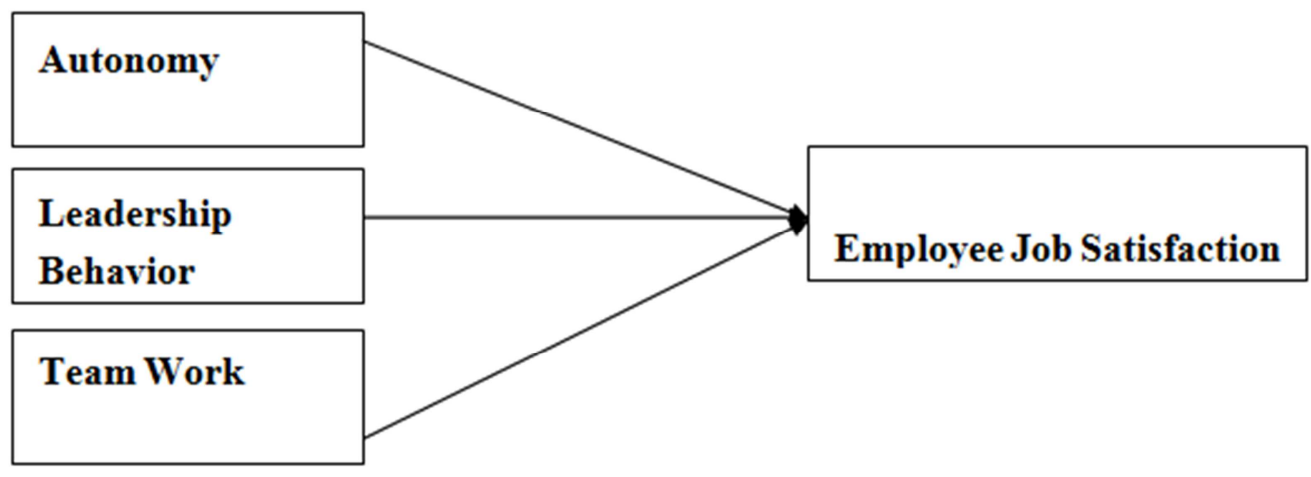

Figure 1. Conceptual Model.

\section{Methods}

\subsection{Sample}

The sample of the study was consisted of 450 employees working in the banking sector in different branches of bank in Bangladesh, of which 295 were returned and processed; a $65 \%$ response rate was achieved. The survey was completed within two and half months from 5th of January to 15th March, 2015. Potential respondents were both men and women aged between 24 to more than 55 years.

\subsection{Measurement}

This study examines the relationship between job satisfaction and human resource management practices like job autonomy, leader- ship behavior and team work environment in Bangladesh banking sector by questionnaire. This questionnaire consisted of two parts; the first part consisted of demographic characteristics of employees whereas, the second part measured the job satisfaction. Likert scale ranking (5-Point likert scale) was used where 5 is the highest degree of agreement and 1 is least degree of agreement. The statistical package social sciences program (SPSS) was used for the analyses. Regression, Correlation and Independent Sample T- Test are applied for analysis in this study. The survey includes instrument to measure the relationship between job satisfaction and human resource practices, divide into four parts, job satisfaction (six items), job autonomy (three items), leadership behavior (five items) and team work (seven items), where job satisfaction is a dependent variable and remaining three are independent variables.

The method of elementary and hierarchical linkage analysis developed by Emery (1997) and further adopted by Williams (1998) to determine the order of association between survey items and job satisfaction in teams, and in the present study same scale was taken from existing study (Williams, 1998) and Job autonomy was measured with three items adapted from Hackman and Oldham (1980). A lot of work has been done regarding to job satisfaction, Garrido et al. (2005) studied the determinants of job satisfaction of sales managers in Spanish industrial firms. Lam et al. (2001) 
studied the managerial job satisfaction in Hong Kong's Chinese restaurants and Oshagbemi (1997) analyzed the job satisfaction levels of teaching staff in universities.

\subsection{Procedure}

This study was based on primary data. The questionnaire was self- administered and was distributed among the 450 respondents. Before giving the questionnaires, all questions were explained to the participants so they can easily complete the questionnaire and the relevant results. Only one questionnaire was given to each respondent. The convenient sampling technique was followed for data collection.

\section{Results and Discussion}

The main objective of the study is to analyze the relationship of different Human resource management practice (autonomy, leadership behavior, team work etc) with job satisfaction. Several tests have been utilized for this analysis and summary of results are given in Table 1. After the getting confirmation about the assumption of equal variances $(p>0.05)$, T-Test is used to estimate the difference in level of job satisfaction level between male and female workers. The result of T-Test indicates that the responses of two groups are significantly different $(p<0.05)$.

Table 1. Level of job satisfaction between male and female employees (independent sample t-test).

\begin{tabular}{lllll}
\hline & Group & Mean & Std Dev & P-Value \\
\hline Level of job & Male & 3.5271 & 0.47041 & 0.030 \\
satisfaction & Female & 3.2015 & 0.48656 & \\
\hline
\end{tabular}

The average value of male respondents is greater than female respondents that is, 3.5271 which are closer to 5 "very satisfied". It is indicating that male employees are more satisfied with their jobs as compared to female employees. The results of the study have supported in literature and represent almost true socioeconomic values and norms which are dominant in the Bangladesh. Women in Bangladesh are faced with the problem of less job opportunities as compare to male. Women consider every job opportunity, available to them, a blessing and are accepted whatever they get. Due to these reasons our results seem to be consistent with the real situation prevailing in Bangladesh. This description of the social norms and values help us to understand the reasons behind the finding of the study that female employees have lower level of job satisfaction as compare to male employees.

The results reported in Table 2 represent the significant correlation among all variables by summarizing the values of Pearson's correlation coefficient. It is clear from the result that at $5 \%$ level of significance job satisfaction is positively correlated with autonomy as the value of the correlation coefficient 0.377 . Leadership behavior is also positively linked with job satisfaction and has statistically significant correlation coefficient 0.476 at $5 \%$ level of significance. Value of Pearson Correlation Coefficient is 0.518 which shows that team work and job satisfaction are highly positively correlated. Their relationship is significant as at 5\% level of significance. Finally, we can say that job satisfaction is positively and significantly correlated with all three independent variables. Employees are not only more aware but they also have more job opportunities due to expansion of the banking sector. The job satisfaction is no more attached only to autonomy it is also accompanied by leadership behavior and team work environment.

The results of regression analysis for job satisfaction are presented in Table 3. The value of R-Square and the value of F-statistic, which are 0.356 and 53.720 respectively, show that the model is significant at the $5 \%$ level of significance ( $p$ $<0.05$ ) and results further show that there is a positive relationship between dependent and independent variables. At 5\% level of significance, the individual coefficients of independent variables are significant. The coefficient of autonomy is 0.124 that can change the job satisfaction 12 percent approximately. A leadership behavior coefficient is significant at $5 \%$ level and it contributes 0.245 or $25 \%$ approximately in job satisfaction. A team work coefficient is significant at $5 \%$ level and it contributes $27 \%$ in job satisfaction. The overall model is significant at 5\% level. All significant variables having varying degrees have their own empirical importance for job satisfaction.

Table 2. Correlation matrix of Male and Female job satisfaction, job autonomy, leadership behavior and team work.

\begin{tabular}{|c|c|c|c|c|c|}
\hline \multirow{3}{*}{ Correlations } & & \multirow{3}{*}{$\begin{array}{l}\text { Job } \\
\text { satisfaction } \\
(\text { Min 1, Max 5) } \\
\end{array}$} & \multirow{3}{*}{$\begin{array}{l}\text { Job autonomy } \\
\text { (Min 1, Max } 5 \text { ) } \\
\end{array}$} & Leadership & \multirow{3}{*}{$\begin{array}{l}\text { Team work } \\
(\operatorname{Min} 1, \operatorname{Max} 2)\end{array}$} \\
\hline & & & & \multirow{2}{*}{$\begin{array}{l}\text { behavior } \\
\text { (Min 1, Max 2) } \\
\end{array}$} & \\
\hline & & & & & \\
\hline Job satisfaction & $\begin{array}{l}\text { Pearson correlation } \\
\text { Sig. (2-tailed) }\end{array}$ & 1 & & & \\
\hline & $\mathrm{N}$ & 295 & & & \\
\hline Job autonomy & $\begin{array}{l}\text { Pearson correlation } \\
\text { Sig. (2-tailed) } \\
\mathrm{N}\end{array}$ & $\begin{array}{l}0.377(* *) \\
0.000 \\
295\end{array}$ & $\begin{array}{l}1 \\
295\end{array}$ & & \\
\hline Leadership behavior & $\begin{array}{l}\text { Pearson correlation } \\
\text { Sig. (2-tailed) } \\
\mathrm{N}\end{array}$ & $\begin{array}{l}0.476(* *) \\
0.000 \\
295\end{array}$ & $\begin{array}{l}0.257(* *) \\
0.000 \\
295\end{array}$ & $\begin{array}{l}1 \\
295\end{array}$ & \\
\hline Team work & $\begin{array}{l}\text { Pearson correlation } \\
\text { Sig. (2-tailed) } \\
\mathrm{N}\end{array}$ & $\begin{array}{l}0.518(* *) \\
0.000 \\
295\end{array}$ & $\begin{array}{l}0.365(* *) \\
0.000 \\
295\end{array}$ & $\begin{array}{l}0.433(* *) \\
0.000 \\
295\end{array}$ & $\begin{array}{l}1 \\
295\end{array}$ \\
\hline
\end{tabular}

** Correlation is significant at the 0.01 level (2-tailed). 
Table 3. Multiple regression coefficients, standard errors in parentheses, $t$-values in brackets and p-values in italics both Male and Female.

\begin{tabular}{|c|c|c|c|c|c|c|}
\hline Dependent variable & Constant & Autonomy & Leadership behavior & Team work & R-square & F statistic \\
\hline Job satisfaction & $\begin{array}{l}0.782 \\
(0.196) \\
(3.999) \\
0.000\end{array}$ & $\begin{array}{l}0.124 \\
(0.032) \\
(3.857) \\
0.000\end{array}$ & $\begin{array}{l}0.245 \\
(0.042) \\
(5.769) \\
0.000\end{array}$ & $\begin{array}{l}0.265 \\
(0.051) \\
(5.197) \\
0.000\end{array}$ & 0.356 & 53.720 \\
\hline
\end{tabular}

As a result of expansion in the banking sector, the employees working in this sector are getting more opportunities and reward. Although, team work is the most important factor affecting job satisfaction, employees give substantial importance to job autonomy and leadership behavior as well.

It is clear from the above results that that job satisfaction level is significantly different for male and female employees as ' $p$ ' value of T-statistic are less than 0.05. Based on these results we may reject the null hypothesis (H0) and can accept the alternate hypothesis (H1) which states that the difference between men and women employees' job satisfaction level is significant and mean value suggests that men employees are more satisfied with their jobs than women workers.

The inferences drawn on the basis of this hypothesis is consistent with the findings of Forgionne and Peters (1982); Weaver (1974) and Shaprio and Stern (1975) who have concluded that men are more satisfied than women. The findings of regression and correlation analysis indicate that job satisfaction is positively and significantly affected with all of three independent variables and employees of Bangladesh banking sector respond the variations in these variables significantly for determination of their level of job satisfaction. Correlation coefficients of autonomy, leadership behavior and team work environment are around 0.5 and $p$ values are less than 0.05 confirm the significance of these independent variables to job satisfaction. The results of the study show that the remaining three hypotheses (H2, H3 and $\mathrm{H} 4)$ are also valid and confirm that autonomy, leadership behavior and team work environment positively related to the level of job satisfaction. These findings are consistent with the work of Garrido et al. (2005) and Lam et al. (2001).

\section{Conclusion, Recommendations and Limitations}

This study aims at measuring the effect of human resource management practices like autonomy; leadership behavior and team work on job satisfaction. It attempts to measure the importance of each factor on level of job satisfaction. It also examines the difference of level of job satisfaction between male and female employees. Findings of the study indicate that there is a positive relationship between autonomy, leadership behavior and team work environment and job satisfaction. However, leadership and teamwork environment influence more than autonomy on employees' job satisfaction. The results also depict a significant difference of level of job satisfaction between male and female employees.

The banking sector in Bangladesh is facing a tremendous change for several years. Not only number of new entrants has increased competition among the banks, but economic condition, political instability and energy crises affected on this industry which affected banking sector. As a result, not only their transaction volume is decreasing, but the number of the transactions is also declining. Due to this banking sector is experiencing rapid turnover. The results of this study are not only beneficial for employers in private banks, but are also useful for public banks. Since this study finds that employees weigh more to leadership behavior and team work environment, than autonomy, to enhance their job satisfaction, so the management should focus on leadership behavior to their employees, and should provide them with a good team work environment which will enhance their level of job satisfaction. It will further reduce absenteeism and turnover. The empirical analysis of this study suggests that male employees should be prioritized when formulating human resource strategies as compared to female employees. Human resource strategies should not be devised on gender discrimination basis but include both categories (Male and female). This study covers the effect factors like autonomy, leadership behavior and team work environment on job satisfaction. A future Research could be carried out by extending the sample size on multidisciplinary industry basis and incorporating other factors (working conditions, employees' safety and security etc).

This study makes contribution in HRM literature by analyzing key factors empirically specific to the banking sector. This study gives importance to priorities three key factor for job satisfaction is not a single factor at all. This will enable employees to reduce the current turnover rate and will increase the level of job satisfaction among employees. Due to insufficiency of empirical literature, it was quite obvious to incorporate the behavior of old workers inform of additional leaves etc. Another limitation of our study is related to sample size selection for analysis. A more comprehensive analysis and generalizability of results demand that sample size should not be specific to financial industry but it should also incorporate multidimensional industrial sample also.

\section{References}

[1] Aydin B, Ceylan A (2009). The effect of spiritual leadership on organizational learning capacity, African Journal of Business Management, 3(5): 184- 190.

[2] Bloom N, Van Reenen J (2007). Measuring and explaining management practices across firms and countries, The Quarterly Journal of Economics, 122(4): 1351-1408. 
[3] Cambell A, Converse P, Rogers W (1976).The Quality of American Life", Russell Sage, New York, NY.

[4] Chow WS, Luk V (1996). Management in the 1990s: A comparative study of women managers in China and Hong Kong, Journal of Management Psychology, 11(1): 24 - 36.

[5] Clark AE (1997). "Job Satisfaction and Gender: Why Women are so happy at Work?”, Lab. Econ., 4: 341-72.

[6] Davis K, Newstrom J (1999).ComportamientoHumano en el Trabajo: ComportamientoOrganizaciona (10th Edn). Mexico: McGraw-Hill.

[7] Dawson P (1987).Computer Technology and the Job of the First-lineSupervisor New Technology, Work Employment. 2(1): 47-59.

[8] Dunkerley D (1975). The Foreman: Aspects of Task and Structure. London: Routledge and Kegan Paul.

[9] Eason KD (1989). Information Technology and Organizational Change. London: Taylor and Francis.

[10] Emery FE (1977).The Emergence of a New Paradigm of Work Canberra: Australian National University, Center for Continuing Education.

[11] Emery FE (1992).The Management of Self-Managing Groups'. In Emery, M. (ed.) Participative Design for Participative Democracy. Canberra: Australian National University Centre for Continuing Education. pp. 165-61.

[12] Forgionne G A, Peters VE (1982). Differences in Job Motivation and Satisfaction among Female and Male Managers, Human Relation, 35(2): 101-118.

[13] Garrido JM, Perez P, Anton C (2005).“Determinants of Sales Manager Job Satisfaction: An Analysis of Spanish Industrial Firms, International Journal of Human Resource Management, pp. 1934-1954.

[14] Gill A, Fitzgerald S, Bhutani S, Mand H, Sharma S (2010). The relationship between transformational leadership and employee desire for empowerment. International Journal of Contemporary Hospitality Management, 22: 263-269.

[15] Gogoi P (2005). A little bit of corporate soul. [Online].Available.http://www.bloomberg.com/bw/stories/200 5-04-04/a-little-bit-of-corporate-soul (Accessed 17 May 2015)

[16] Guest DE (2004). "Flexible employment contracts, the psychological contract and employee outcomes: an analysis and review of the evidence". International Journal of Management Review, 5/6 (1): 1-19.

[17] Hackman J, Oldham G (1980). Work Redesign”, AddisonWesley,Reading, MA.

[18] Hackman JR (1990). Groups That Work (and Those that Don't). San Francisco: Jossey-Bass.

[19] Ivancevich J, Olelans M, Matterson M (1997). Organizational Behavior and Management, Sydney: Irwin.

[20] James D (1996). Forget Downsizing, Now It's Participative Redesign, Bus. Rev. Weekly. 18(46): 70-72.

[21] Lam T, Baum T, Pine R (2001). Study of Managerial Job
Satisfaction in Hong Kong's Chinese Restaurants, Int. J. Cont. Hosp. Manage., 13(1): 35-42.

[22] Lee E, Ho H (1989). Quality of work life the case of Hong Kong, Working Paper Series, Hong Kong Baptist College: Business Research Center, Hong Kong.

[23] Markow K, Klenke K (2005). The effects of Personal meaning and calling on Organizational Commitment: An empirical investigation of Spiritual Leadership, International Journal of Organizational Analysis, 13: 8-27.

[24] Milliman J, CzaplewskiAJ, Ferguson J (2003). Workplace spirituality and employee work attitudes: an exploratory empirical assessment, Journal of Organizational Change Management, 16: 426-447.

[25] Nguyen A, Taylor J, Bradley S (2003). Relative Pay and Job Satisfaction: Some New Evidence, MPRA Paper No 1382.

[26] Oshagbemi $\mathrm{T}$ (1997). Job satisfaction profiles of university teachers, Journal of Management Psychology, 12(1): 27-39.

[27] Oshagbemi T (2003). Personal Correlates of Job Satisfaction: Empirical Evidence from UK Universities, International Journal of Social Economics, 30(12): 1210 - 1232.

[28] Patel PC, Cardon MS (2010).Adopting HRM Practices and Their Effectiveness in Small Firms facing Product Market Competition, Human Resource Management, 49(2): 265-290.

[29] Petrescu AI, Simmons R (2008). Human resource management practices and workers' job satisfaction, International Journal of Manpower. 29(7): 651- 667.

[30] Silla I, Gracia F, PeiróJM (2005).Job insecurity and healthrelatedoutcomes among different types of temporary workers, Economics and Industrial Democracy, 26: 89-117.

[31] Sels L, De Winne S, Maes J, Delmotte J, Faems D, Forrier A (2006). Unravelling the HRM-performance link: Valuecreating and cost- increasing effects of small business HRM, Journal of Management Studies, 43(2): $319-342$.

[32] Shaprio J, Stern L (1975). Job Satisfaction Male and Female, Professional and Non-Professional Workers, Personnel.Journal, 54: 9- 388 .

[33] Smith DK (1993). The Wisdom of Teams. Boston, MA: Harvard University Press.

[34] Tanke ML (1990). Human Resources Management for the Hospitality Industry, Delmar Publishers, Albany, NY.

[35] Voon, M. L., \&Ayob, M. C. (2011) The influence of leadership styles on employees' job satisfaction in public sector organization in Malaysia. International Journal of Business, Management\& Social Sciences, 2(1), 24-32

[36] Ward M, Sloane P (1998). Job Satisfaction: The case of the Scottish Academic Profession, Mimeo, University of Aberdeen, Aberdeen.

[37] Weaver CN (1974). Correlates of Job Satisfaction: Some Evidence from the National Surveys, Academy of Management Journal, 17: 373-375.

[38] Williams T (1998). Job satisfaction in teams", International Journal of Human Resource Management, 9(5): 782-799. 